Fall 10-2014

\title{
How Secular Should Democracy Be? A Cross-Disciplinary Study of Catholicism and Islam in Promoting Public Reason
}

\author{
David Ingram \\ Loyola University Chicago, dingram@luc.edu \\ David Ingram \\ Loyola University Chicago
}

Follow this and additional works at: https://ecommons.luc.edu/philosophy_facpubs

Part of the American Politics Commons, Comparative Politics Commons, Eastern European Studies Commons, Latin American Studies Commons, Legal Studies Commons, Near and Middle Eastern Studies Commons, Philosophy Commons, Political Theory Commons, Politics and Social Change Commons, Social Psychology and Interaction Commons, Sociology of Religion Commons, and the Theory, Knowledge and Science Commons

Author Manuscript

This is a pre-publication author manuscript of the final, published article.

\section{Recommended Citation}

"How Secular Should Democracy Be? A Cross-Disciplinary Study of Catholicism and Islam in Promoting Public Reason," Politics, Religion, and Ideology: Special Edition on Secularism, ed. Claudia BaumgartOchse, Faiz Sheikh, et. Al; 15/3 (2014): 1-21.

This Article is brought to you for free and open access by the Faculty Publications and Other Works by Department at Loyola eCommons. It has been accepted for inclusion in Philosophy: Faculty Publications and Other Works by an authorized administrator of Loyola eCommons. For more information, please contact ecommons@luc.edu. cc) (i) $(9)$

This work is licensed under a Creative Commons Attribution-Noncommercial-No Derivative Works 3.0 License. (C) 2014 Taylor \& Francis 
How Secular Should Democracy Be? A Cross-Disciplinary Study of Catholicism and Islam in Promoting Public Reason

\section{David Ingram}

Loyola University Chicago

Philosophy Department

1032 W. Sheridan Road

Chicago, Illinois

Office: $773-508-2299$

Email: dingram@luc.edu 


\begin{abstract}
I argue that the same factors (strategic and principled) that motivated Catholicism to champion liberal democracy are the same that motivate $21^{\text {st }}$ Century Islam to do the same. I defend this claim by linking political liberalism to democratic secularism. Distinguishing institutional, political, and epistemic dimensions of democratic secularism, I show that moderate forms of political and epistemic secularism are most conducive to fostering the kind of public reasoning essential to democratic legitimacy. This demonstration draws upon the ambivalent impact of Indonesia's Islamic parties in advancing universal social justice aims as against more sectarian policies.
\end{abstract}

Thirty years ago Edward Said's iconic treatise on orientalism indicted Western imperialism and its academic apologists for having deployed the ideology of cultural differences in depicting Arab-Islamic culture as inherently despotic, backward, and antithetical to secular Occidental culture. ${ }^{1}$ This orientalist ideology has continued to persist among those who find in Christendom and Islam new enemies to replace the ideological adversaries of the Cold War. ${ }^{2}$ As Bryan Turner remarks, ${ }^{3}$ this new ideological opposition between a rationalized Christendom and a premodern Islam is deeply problematic at a number of levels: both religious worldviews share common Abrahamic origins and values; Islam established itself as an Occidental society in Spain, Malta, and the Balkans; and Islam preserved, developed, and disseminated the intellectual legacy of classical Greece that formed the identity of Christendom and Occidental rationality.

For Turner, the global conflict facing us today is not ideological but social and economic. The spread of "postmodern" global capitalism with its commodification of culture, undermining of communitarian identities, and reduction of persons to individually self-centered

${ }^{1}$ E. Said, Orientalism (New York: Pantheon Books, 1978).

${ }^{2}$ Bernard Lewis, What Went Wrong? The Clash Between Islam and Modernity in the Middle East (New York: Harper Collins, 2002).

3B. Turner, Orientalism, Postmodernism, and Globalism (London: Routledge, 1994). 
consumers has provoked a religious backlash that is felt as much by Christian fundamentalists as by Islamic fundamentalists. Although it pushes against an excessively materialistic form of secularism, this backlash also targets an idealistic variant: multiculturalism. Multiculturalism undermines fundamentalism's nostalgic yearning for certain and stable identities. Although many fundamentalists respond to this threat by withdrawing from civil society, others instead respond by projecting their desire onto the democratic state. Rejecting liberal and pluralistic ideals of self-limiting democratic compromise, they envision the totalitarian suppression or subordination of competing identities as a way of legally and politically cementing their own.

This apparent hostility to secularism, pluralism, and democratic compromise, however, is belied by a further idealistic component within the Islamic/Christian imaginary: a transcendent commitment to social justice. Political opposition to postmodern capitalism's stratifying dynamic, which contradicts the holy command to combat material oppression on this earth, strongly encourages religious fundamentalists to pursue a secular agenda whose broad scope and success requires a modest - and I will argue reasonable - acceptance of self-limiting compromise and political argumentation. Secular commitment to a political value that is universal and thus free-standing with respect to religion and every comprehensive ideological orientation - social justice for believer and non-believer alike - converges with a form of political liberalism that demands multicultural toleration of all reasonable comprehensive doctrines (religious and secular) to the extent that these doctrines overlap in supporting the political value in question.

In making this argument, I will draw upon on an analogy between the trajectory that some moderate Islamist parties in Indonesia have taken in furthering secular democracy in the name of social justice, and that taken by Catholicism, whose antagonism toward liberalism and secular democracy, having reached their apogee over a hundred years ago, is perhaps less well known. 
Catholicism largely overcame its hostility to secular democracy and became a major force for advancing democracy in the last three decades of the $20^{\text {th }}$ Century. I maintain that the factors that led political Catholicism along this trajectory are also at work in some varieties of political Islam.

Addressing both Catholic and Islamic strands of religious politics along with their ambivalent relationship to secular democracy, I believe, shows us that religious politics and secular democracy shape each other, as both in turn respond to deeper socio-economic changes in their environment. However, defending the compatibility of religious politics and secular democracy will require drawing some rather fine-grained distinctions, not only between different kinds of religious politics but also between different kinds (and aspects) of secular democracy. When speaking of secular democracy political scientists normally focus on the institutional separation of religion and state. Equally important, however, is the political culture; viz., the degree of democratic toleration and civility religious political parties display in furthering their aims. Closely connected to this political secularism is an epistemic secularism, or the capacity, as Rawls puts it, for religious parties to accept the "burdens of judgment" in refraining from imposing religious doctrines or appealing to religious rationales whose truth cannot in principle be demonstrated to all. While it may seem that extreme epistemic secularism correlates with political secularism, I shall argue that religion is sometimes a better stimulus to creating and preserving secular democracy.

I begin (Part One) by examining the problem of secularism in the Muslim world. I argue that Islamic thought and practice reveal a spectrum of epistemic, political, and institutional forms, some more secular than others. In the second half of the $20^{\text {th }}$ Century, reaction against Western secularism led many Muslim countries to adopt hybrid institutional forms, involving 
dual (religious/secular) jurisdictions and dual systems of legitimation and administration. Despite their hybridity, such forms arguably meet a threshold of democratic secularity.

Politically speaking, however, Islamist support for blasphemy laws and other policies reflecting Islamic doctrine (as in Indonesia) raise a different set of questions about the compatibility of political Islam and secular politics. I continue (Part Two) by examining these questions within the context of debates about religion-based limitations on free expression (obscenity) in the United States and secular limitations on free religious expression in France. Comparing French and American paradigms of religion-state separation (or hybridity) as representative of strong and moderate paradigms of political secularism, I contend that neither paradigm presents a religion-neutral interpretation of what counts as a reasonable inclusion of humanistic or religious expressions in the public sphere. Drawing on Charles Taylor's normative criteria of secular democracy, I argue that strongly secularist democracies such as those institutionalized in France and Turkey fail to balance the criterion of fraternity against criteria of freedom, equality, and public inclusion.

Concluding that standards of reasonable inclusion must be negotiated in the public political sphere as suggested by the more moderate, American paradigm of secularism, I turn (Part Three) to the problem of specifying the precise moral limits of such negotiation. Drawing from Muslim as well as Catholic and agnostic thinkers, I argue that "public reason" cannot be interpreted as peremptorily excluding comprehensive faith commitments from its purview, although such commitments must conform to the moral requirements of secular democratic debate in order to claim legitimacy. 
In answering why we should expect religious political movements to evolve from strategically motivated, qualified acceptance of these requirements (modus vivendi) to unqualified acceptance based on moral principles, I argue (Part Four) that the social justice concerns of religious political movements lead these movements to broaden their appeal beyond narrow doctrinaire platforms. This conclusion is further supported by comparing the role that Islamic movements played in Indonesia's peaceful transition to secular democracy to the role that Catholic movements played in the "third wave" of democratic reform in Europe and South America.

Part One: Secularism in the Muslim World: Epistemic, Institutional, and Political Aspects

In 2013 five girls were charged with having violated Indonesia's blasphemy law (Article 156a of Indonesia's penal code) that prohibits "staining religion, adhered to in Indonesia ... with the intention to prevent a person to adhere to any religion based on the belief in the almighty God." Specifically, the girls shot a video of themselves dancing to a pop song while reciting prayers from the Qur'an. They face up to five years in juvenile detention if convicted. In an earlier (2010) case involving the free exercise of religion, Indonesia's Constitutional Court rejected a challenge to the blasphemy law, noting that prohibiting expression of religious beliefs that deviate from the central tenets of any one of Indonesia's six officially recognized religions was necessary for protecting public safety and order. (In 2008 officials invoked the law to suppress the religious practices of the Ahmadiya, who believe Mohammad will be followed by another prophet, after members of the National Alliance for the Freedom of Faith and Religion who had 
peacefully demonstrated on behalf of religious pluralism were attacked by 500 Islamist militants.) Four months prior to the court decision, President Susilo Bambang Yudhoyono had opened the Sixth Assembly of the World Movement for Democracy by proclaiming: "We in Indonesia have shown, by example, that Islam, democracy, and modernity can grow together. We are a living example that there is no conflict between a Muslim spiritual obligation to Allah (and) his civic responsibility as a citizen in a pluralist society" (my stress).

Human Rights Watch disagreed with this assessment, condemning the court's 2010 decision as a stark endorsement of religious intolerance. ${ }^{4}$ Hence the question: Who is right Human Rights Watch or the President and the court? Indonesia's 1945 Constitution guarantees freedom of religion in Article 28e and in 2006 Indonesia ratified the International Covenant on Civil and Political Rights, which guarantees that members of religious minorities "shall not be denied the right, in community with other members of their group ... to profess and practice their own religion." So either the blasphemy law contradicts Indonesia's constitutional guarantee of religious freedom and its international legal obligations or it qualifies this civil and political right in ways that are compatible with citizenship in a secular democracy.

The same question can be asked about the law's prohibition against "tainting religion." Is this prohibition less problematic because it targets all disrespectful displays of religion regardless of denomination? Or does it too violate a basic civil and political right to free expression? In general, if delimiting the range of free expression of religion as it applies in this instance and in cases involving the toleration of minority confessions requires reasonably balancing conflicting

\footnotetext{
4"Indonesia: Court Ruling a Set Back for Religious Freedom," (http://www.hrw.org/news/2010/04/19/Indonesia).
} 
values (freedom versus public order, fraternal pluralism versus majoritarian democracy), then to which cultural and political standards of reasonableness should one appeal?

To probe this question more deeply we need to understand how the secular conditions of modern pluralism and democratic civic responsibility mentioned by President Yudhoyono are not in conflict with (as he puts it) "a spiritual obligation to Allah.” The secular conditions of modern pluralism and democratic civic responsibility are institutional, political, and epistemic, with each of these terms referring to a limitation on the absolute and all-encompassing authority of religion vis-à-vis worldly matters. Simplifying further, I distinguish between strong, moderate, and weak forms of secularism.

Strong epistemic secularism (SES): Reduction of knowledge to what can be confirmed using scientific methods (positivism). Corresponding to methodological positivism is skepticism about the meaningfulness or truth of non-factual value judgments and religious revelations.

Weak epistemic secularism (WES): Recognition of scientific knowledge and religious revelation as distinct sources of knowledge. As in the case of science, where one paradigm is recognized as factually authoritative, one religion is privileged as the sole true paradigm of values and norms. Stronger WES recognizes a plurality of authoritative religions.

Moderate epistemic secularism (MES): Recognition of the complementarity of science and religion and the interpenetration of facts and values. MES acknowledges both utilitarian calculations and rational consensus among comprehensive belief systems as worldly sources of moral knowledge. MES views religion as a primary source for secular 
values revolving around the fundamental dignity of the individual and the common good, and rejects extreme forms of materialistic humanism (psychological and moral egoism) as well as scientific positivism as reductionist ideologies. MES condemns value skepticism and radical relativism while treating all knowledge as value-laden, interpretative, contextual, and fallible.

Strong institutional secularism (SIS): State suppresses public expression of religion as incompatible with a national "civic religion." Suppression ranges in strength from institutional atheism (as in the former USSR and its client states) to institutional laicism (as in present-day France and Turkey).

Weak institutional secularism (WIS): Within a pluralist framework permitting freedom of thought and religion, state privileges one religion (confessional state) or perhaps several religions. Weaker forms expressly derive some or all constitutional rights, duties, and norms from a privileged religion (or religions).

Moderate institutional secularism (MIS): Constitutional separation of religion and state compatible with some state involvement in religion. Separation is compatible with dual jurisdictions delegating some areas of private law arbitration to religious courts (as in India and some Muslim majority countries).

Strong political secularism (SPS): Citizens and political parties bracket religious motives and values when voting or advocating on behalf of policies.

Weak political secularism (WPS): Citizens and political parties mainly appeal to religious motives and values when voting or advocating on behalf of policies. 
Moderate political secularism (MPS): Citizens and political parties interpret their religious motives and values in conformity with broadly shared secular values and norms. Citizens and political parties recognize and value religious pluralism and refrain from imposing religiously motivated policies that cannot be justified on non-religious grounds.

Explanation: Essential to all forms of secularism is a separation, partial or complete, of religion from worldly knowledge, law, and politics. Although one might suppose that strong, weak, and moderate forms of secularism tend to correlate across categories, I do not provide evidence for this. Polities characterized by WPS (Iraq) or SES (Germany) might both endorse MIS. Further complicating this picture is the anomalous nature of SIS and WIS as descriptors that apply equally to ideological regimes of a nationalist or civic humanist stripe.

The above analysis articulates the multidimensional relationship between Islam and secular democracy in a way that links epistemic and political competencies. Turning first to the epistemic dimension of the relationship, we note that two Arabic words for secularism, almaniyya and ilmanniyya, have as their roots alam (worldliness) and ilm (scientific knowledge). These two concepts are touched upon in at least one sacred Muslim text. One chapter of the Sahih of Imam Muslim, the second most authentic book on Hadith, dating back to the Second Century Hijrah, is entitled: "Whatever the Prophet has said in matters of religion must be followed, but this does not apply to worldly affairs."

Although centuries of Islamic secular philosophy and science dating back to Averroes understand this hadith as endorsing MES, it bears remembering that some Islamic thinkers in the modern era, like their Catholic counterparts during the Renaissance, equated the Western enlightenment with SES. Both Islam and Catholicism had to confront the challenge of modern 
science, but Muslims living under colonial rule and in modernizing Middle Eastern states premised on SIS witnessed their traditional madrasas and religion-based educational traditions suppressed and replaced by public schools that were perceived as enforcing SES. Subsequent reaction against this Westernizing influence produced hostility towards more moderate forms of institutional secularism.

Turning to the institutional aspect of secularism, scholars in Muslim countries have long debated whether and to what extent political and legal systems fall into the spiritual realm of moral and ethical regulation or the worldly realm of scientific administration and rational choice. Those scholars, who argue that the "spiritual" domain regulated by the Qur'an and Hadith extends to the political and social realm, will find little in these texts pertaining to the structure of a just state, as distinct from the structure of a just society. ${ }^{5}$ Some scholars, including noted political theorist Abdullahi Ahmed An-Na'im, insist that provisions of shari'a based exclusively

Some scholars have argued that the different way in which Christian and Muslim theologians working within a reason-based, natural law context have traditionally interpreted human nature divided (sinful) versus undivided - seems to correlate with opposing views of legal authority, with Islam favoring less divided forms of government that would be less amenable to separation of religion and state. Indeed, some scholars have made the more sweeping claim that Islam, or Muslim culture broadly construed, seems less accepting of social conflict as a necessary and unavoidable - and perhaps even positive - feature of modern political life. From this shaky premise they conclude that in cases of conflict any rational interpretation of shari' $a$ that takes into account its four sources - the Qur'an, hadith, consensus, and analogical reasoning - will privilege the common good over individual rights, including, as we saw in the case of Indonesia, the civil rights of religious minorities. See R. Powell, "Toward Reconciliation in the Middle East: A Framework for Muslim-Christian Dialog Using Natural Law Tradition,” Loyola University Chicago International Law Review, v. 2, n.1 (2004). 
on a literalist reading of the Qur'an and Hadith are problematic in that they subordinate women to men, deny non-Muslims full civil and political rights and require them to pay a special tax, and condemn Muslims who abandon their faith. These provisions, when legally imposed, appear to violate human rights, at least insofar as these rights are fully understood to apply to all individuals equally, pursuant to Articles 1-3 of the Universal Declaration of Human Rights (1948). ${ }^{6}$

However, An-Na'im also argues that an interpretation of the Qur'an, based on the early Mecca teachings of Mohammad, before the flight to Medina and the establishment of a Muslim state, permits accommodation with liberal human rights, gender equality and democratic ideals, and even requires the religious neutrality of the state (quoting Surah 256 of the Qur'an, which commands that "there shall be no compulsion in religion"). Historically, in fact, the four Caliphs that followed Mohammad were chosen by the community of converts (umma) as spiritual interpreters of shari'a based on their personal association with him, but they were not administrators of a coercive state apparatus in the full sense of the word. Concluding that these caliphates did not amount to a fusion of state and religion, Ira Lapidus adds that later dynastic rulers of the Ummayyad (661-750), Abbasid (750-1258), Mameluke (1250-1517) and Ottoman empires (1299-1922) were state administrators who, however, instituted a divided government along the

\footnotetext{
${ }^{6}$ A. A. An-Na'im, Toward an Islamic Reformation: Civil Liberties, Human Rights, and International Law (Syracuse: Syracuse University Press, 1990), p. 21; and Islam and the Secular State: Negotiating the Future of Shari'a (Cambridge: Harvard University Press, 2008). But as Alessandro Ferrara notes (The Democratic Horizon: Hyper-Pluralism and the Renewal of Political Liberalism (Cambridge: Cambridge University Press, 2013), ch. 5), in Muslim contexts individual rights are typically invoked in a restorative manner, as compensations for torts and damages, rather than as "natural properties" of persons that serve to delimit state power and "trump" duties to the community.
} 
lines of the doctrine of two swords that prevailed in Medieval Christendom, which conceded distinct domains of legal jurisdiction to secular and religious authorities. ${ }^{7}$ The Sultans and Emirs did protect the Muslim faith from internal and external enemies and they sought to institute shari'a but, as Olivier Roy observes, they derived most of their legitimacy from their political and administrative functions, such as the power to coin money and preserve order. ${ }^{8}$

Today, many majority-Muslim governments that have secular constitutions permit Muslims to settle family and property disputes in shari'a courts. Others that constitutionally entrench shari' $a$ as a system of higher legitimating values and principles (such as Iraq and Pakistan) institute secular forms of democratic governance legitimating legislation and public law adjudication. Again, in the wake of the recent Arab Spring uprising, Tunisia's 2014 Constitution entrenches Islamic values (Article 1) while guaranteeing full and equal religious freedom for all (Article 6). In the case of Indonesia, we find yet another variety of this example of religious legitimation of secular democracy, expressed in the non-sectarian principle of pancasila (see below). Hence we may describe these institutional arrangements as lying somewhere between WIS and MIS.

The manner in which shari' $a$ has been institutionalized in the legal and political institutions of majority-Muslim states today has been shaped by Islamist political movements that arose in reaction to home-grown and foreign- imposed secular governments. Many of these

${ }^{7}$ Ira M. Lapidus, "The Separation of State and Religion in the Development of Early Islamic Society", International Journal of Middle East Studies vol. 6, no 4 (October 1975): 364.

${ }^{8}$ Olivier Roy, The Failure of Political Islam (Cambridge: Harvard University Press, 1994, 14-15. 
governments were deemed to be hostile to the moral and social justice precepts of Islam. Some of them, such as Gamar Abdel Nasser's in Egypt, were inspired by Arab nationalism and socialism, and so regarded Islamists as a divisive force that needed to be repressed. Indeed, even Pakistan, a regime founded on Islam, has suppressed fundamentalist Islamist groups opposed to its weakly secular form of government.

However, as noted above, most Muslims endorse some religious involvement in politics and so reject the banishment of religion from the public sphere that once existed in Iran (under the Pahlavi regime) and still existed in Turkey until recently. Leaving aside fundamentalists, ${ }^{9}$ many Sunni moderates derive their political commitment to democratic and human rights reform from the $8^{\text {th }}$ Century Hanifite School, whose interpretation of shari'a emphasizes the role of analogical reasoning and rational deliberation about the common good above traditional consensus (ijma) and textual literalness. Khalid Abou el Fadl of the Usali school of jurisprudence is a well-known critic of Wahhabism and a defender of human rights. ${ }^{10}$ Rashed Ghannouchi, who helped draft Tunisia's constitution - considered to be among the most secular and politically liberal in the Arab world - and found the moderate Ennahda Party, likewise advocates political liberalism.

${ }^{9}$ For a detailed discussion of Islamic fundamentalism (especially Wahhabism and the origins of the Hanbali legal school) and its relationship to the Shafi'ite, Malakite, and Hanafi schools, see Nazih Ayubi, Political Islam: Religion and Politics in the Arab World (London: Routledge, 1991) and Josef van Ess, The Flowering of Muslim Theology (Cambridge, MA: Harvard University Press, 2006.)

${ }^{10}$ Khalid Abou el Fadl, The Great Theft: Wrestling Islam from the Extremists (San Francisco: Harper, 2005). 
Shiism and branches of Sufism (which emphasizes mystical revelation) also interpret the Qur'an this way, and the Mevlevi order, founded in thirteenth century Turkey, and the Republican Brotherhood, founded in the twentieth century by the Sudanese scholar Mahmoud Mohamad Taha (of which An-Na'im is a follower), especially emphasize the blending of spiritual exercises and secular moral and political thought. A striking example of a modernizing Shiite movement is the Iranian Reform Front, which briefly came to power under the presidency of Mohammad Khatami (1997-2005). Khatami’s call for a “dialogue of civilizations” was also a call to come to terms with globalization and anti-Western fundamentalism in ways that resonate with the account of democratic public reason I discuss below. ${ }^{11}$

As for stronger secular reform movements, the "Young Turks" who came to power following the collapse of the Ottoman Empire illustrate a different kind of tension that can exist between certain Western ideals of enlightenment associated with SES, SIP, and SPS and liberal democracy. The example of Turkey also illustrates how complicated state/religion relationships can be even in governments that have instituted a rather severe form of state/religion separation. The Turkish Republic's former ban on religious parties and public displays of religious symbolism (dating back to Mustafa Kemal's obsession with combating religious divisiveness in the founding years of the republic) resembles the laïcism of the French Republic (see below), even though the Religious Affairs Directory appoints imams, issues religious decrees (fatwas), mandates religious education, and shapes curriculum according to its own flexible and rational

\footnotetext{
${ }^{11} \mathrm{~A}$ good discussion of this singular moment in the history of the Islamic Republic of Iran may be found in Günes Tezcür, The Paradox of Moderation: Muslim Reformers in Iran and Turkey (Austin: University of Texas Press, 2010),
} 
adaptation of the Qur'an. The permission granted to the AK (Justice and Development) Party by the military (the official guardians of the Turkish constitution) to form a government in 2002 marked an important step toward liberalization, since the AK's platform, informed as it is by the toleration characteristic of Turkish Sufism, advocates a modestly pluralistic society in which most religious and non-religious beliefs are permitted public expression, within limits. ${ }^{12}$

Let me now conclude this section by returning to the example of Indonesia, whose problematic blasphemy law provoked our discussion. Aside from the Iranian Revolution of 190506, whose broad public support issued in a relatively liberal and democratic constitutional monarchy, Indonesia's young constitutional government arguably approximates the liberal democratic ideal more closely than any other in the Muslim world. Indonesia's democracy followed upon the resignation of General Suharto and his often brutal "New Order" regime that ruled from 1965 to 1998. Like the Islamic democracy that emerged in the wake of the 1979 Iranian revolution, it reacted against an oppressive authoritarian government. Although the government it replaced was at best weakly secular - the Suharto regime increasingly advanced Islamic policies to divide the opposition and gather popular support - it was nonetheless condemned by many pious Muslims for siphoning off vast amounts of wealth for its own privileged elites while ignoring the spiritual and material needs of its poorest citizens. ${ }^{13}$

\footnotetext{
${ }^{12}$ Günes Tezcür, "Constitutionalism, Judiciary, and Democracy in Islamic Societies, Polity 39/4 (October 2007), pp. 479-501. This same author notes (Paradox of Moderation, 80) that the AK has been halfhearted in its support for religious freedom for the Alevis.
}

${ }^{13}$ Robert Hefner, His Civil Islam (Princeton: Princeton University Press, 2000), esp. chs, 6-7. 
Indonesians thus supported moderately secular democratic reform in direct opposition to a corrupt and brutal dictatorship that often masqueraded as Islamist.

I shall have more to say about the positive contribution that political Islam made to this reform in the conclusion. Suffice it to say, the reform is powerful evidence - along with the historical sources cited at the outset of this discussion - that Islam, like most religions, represents a complex web of epistemic, political, and institutional orientations that can accommodate a variety of secular democratic forms. Particularly striking is the way in which these forms incorporate religious elements. SIS regimes like Turkey combine laïcism and Islamic education; WIS regimes like Iraq and Tunisia promote religious freedom under the aegis of shari'a. And Indonesia's similar constitutional provisions are officially upheld by religious principles that, as I argue in the conclusion, cast aspersions on its blasphemy law, or at least the court's application of it.

However, before deciding whether that law runs afoul of these principles, and more important, whether religious interventions in support of restricting freedom of speech might be undertaken in a manner that is reasonable and legitimate according to at least moderate forms of secular politics, I propose that we first look at the problem from the opposite standpoint and ask whether secular restrictions on public religious expression (broadly construed to include visual displays as well as speech) and other restrictions that burden the free exercise of religion violate reasonable and legitimate forms of secular politics. A brief review of this question as it has been debated in two opposed, iconic systems of Western democratic secularism - France and the United States - will help us answer the broader question concerning the normative limits of reasonable secular politics. 


\section{Part Two: Secular Democracy in Christendom: Preliminary Sociological Observations}

In Christendom as in Islam, 'secular' and 'secularization' have multiple meanings. Although in Christian contexts 'secular' roughly means 'non-religious,' 'secularization' can also connote a process immanent within religion. Ecclesiastic usage refers to the act of releasing monks from their vows; historical usage refers to the selling off (or confiscation) of church property. It may also have referred to the spread of Christianity beyond the Jewish community and its assimilation to Roman culture.

This latter meaning partly resonates with the sociological meaning of secularization, understood as a process whereby parochial religious images, such as the Christian image of humanity made in the likeness of God, are rationally reinterpreted as universal ideas (e.g., the equal and inherent dignity of the individual as a bearer of human rights). It is in this latter sense that Weber saw the ethical heritage of Abrahamic faiths as conducive to providing the cultural foundation for modernization. That said, he believed that only Christianity - specifically Protestantism - provided the "spiritual" conditions for realizing modernity as a distinctly rational form of capitalist society ${ }^{14}$ thereby relegating Islam to the status of a static premodern worldview. ${ }^{15}$ As Turner correctly notes, this orientalist bias obscures the fundamental

${ }^{14} \mathrm{M}$. Weber, The Protestant Ethic and the Spirit of Capitalism (1905).

15 Weber did not live to finish his study of Islam to complement his other volumes on sociology of world religion (1920-21): Ancient Judaism, The Religion of China, and The Religion of India. His scattered remarks on Islam argue that "Islam was never a religion of salvation" that could inspire worldly asceticism conducive to capitalism in the way that Christianity could. Islam, he contended, was disseminated by warriors who sought salvation through holy war (jihad) and territorial expansion. The feudal property system they established tolerated slavery, serfdom, and external, ritual deference to shari'a but no internal ethical commitment to personal responsibility. Complementing Islam's legalism, which vested the qadi with ad hoc law creating powers in interpreting the vague and unsystematic corpus of shari'a, was an 
ambivalence of both Islam and Christianity toward capitalism, to which these worldviews can be at once accommodating and resistant. ${ }^{16}$

Indeed, the classical sociological tradition of Marx, Weber and Durkheim linked the 'rationalization' of religion to its decline. Weber, for instance, argued that rationalization "disenchants" the cosmos and breaks apart comprehensive world views into distinct cultural value spheres revolving around law and morality, science and technology, and art and eros. Accompanying this pluralization of cultural spheres is a corresponding differentiation of social structures (state, economy, and family). In tandem with this process we also observe a functional differentiation of social and vocational roles, a pluralization of comprehensive belief systems, and an individualization of persons' self-understanding. ${ }^{17}$ According to this theory of secularization, whatever vestiges of religious faith remain are relegated to the back burner of private moral conscience, whose unconditional moral imperatives - seemingly necessary for under-girding the weak civil solidarity of a hyper-individualist, contractualist society - gradually

inward-looking, but mystical and otherworldly, Sufism. M. Weber, Sociology of Religion (London Methuen, 1965), pp. 263-4.

${ }^{16}$ Turner argues that much of Weber's explanation for Islam's failure to provide fertile ground for capitalism - its alleged lack of inwardness and asceticism, formal systematic legal structure, and acceptance of commerce - are faulty. The Qur'an discusses commerce in a noncondemning tone and exhorts the believer to ethical conduct conducive to ascetic salvation; meanwhile Anglo-American common law with its judge-made case law approach parallels qadi law in its lack of systemic unity. But Turner observes that one part of Weber's explanation does ring true, although it is extrinsic to his discussion regarding the spirit of Islam: patrimonial war lords destroyed a once-thriving money economy by seizing property and land through arbitrary taxation and lawless means. B. Turner, "Islam, Capitalism, and the Weber Thesis,” British Journal of Sociology 25/2 (1974): 230-43.

${ }^{17}$ M. Weber, The Sociology of Religion (Boston: Beacon, 1993), pp. 223-45. 
give way to the prudential calculations of economic life. Compromising competing economic interests now becomes the chief business of democratic politics, replacing efforts to convert others to the true faith.

In the face of an alienated daily regimen of work and consumption, Weber also discerned a counter-yearning for charismatic leadership and solidarity, which, as we know today, can take modern secularist or anti-modern anti-secularist forms, inspiring either progressive criticism of the social injustices and pathologies of capitalism or regressive nostalgia (nationalist or fundamentalist) for lost identity and community. Iranian philosopher and moderate Islamist Abdolkarim Soroush emphasizes the epistemic dimension of this divide: "From an epistemological point of view, the presecular (or premodern) age is marked by the hegemony of metaphysical thought in political, economic, and social realm," which modernity unsettles, such that "no values and rules are beyond human appraisal." 18

Although the decline of religion is observable in some modern (mainly European) democracies, what is striking today in the West is the persistence and resurgence of religion alongside moderate forms of epistemic, political, and institutional secularism. For this reason contemporary secularization theorists such as Charles Taylor propose a more nuanced view regarding the transformation of religion in modern society. ${ }^{19}$ Assuming that secularism does not

\footnotetext{
${ }^{18}$ A. Soroush, Reason, Freedom, and Democracy in Islam: Essential Writings of Abdolkarim Soroush (Oxford: Oxford University Press, 200), p.p. 54-55, 57, 60.
}

${ }^{19}$ C. Taylor, A Secular Age (Cambridge: Harvard University Press, 2007); J. Casanova, Public Religions in the Modern World (Chicago, University of Chicago, 1994). 
destroy religion, it may lead to its privatization; but where religion continues to play a significant role in public affairs, it can take either moderate or antagonistic forms. As we saw in the case of moderate Islamic secularism, it can also assume a pluralization of religious forms, in which religion co-exists alongside of, or mixes with, other non-theistic orientations in a constellation that falls short of prescribing a fully comprehensive way of life.

Taylor extends this analysis of religious pluralism to his discussion of secular democracy. Rejecting the standard view that democracy demands a strict separation of church and state along the lines of SIS - a definition which, among other things, would impugn the secularity of nominally confessional democracies such as Great Britain, Denmark and Finland - he notes three requirements of modern pluralism (roughly corresponding to the French Revolutionary trinity of liberty, equality, and fraternity) that such democracies must satisfy if they are to meet the minimal criteria of MIS: they must permit the most extensive individual exercise of religious freedom compatible with a like freedom for all; they must not privilege one religious outlook over another; and they must include all religious outlooks in the democratic shaping of public opinion - a feature that is the focus of my paper. ${ }^{20}$ Recognizing the danger of social conflict posed by allowing one (or several) religions hegemonic influence in shaping public opinion (and recalling Indonesia's suppression of the Ahmadya), Taylor recommends supplementing the third requirement with a fourth requirement: secular democracies must balance these three goals in a way that conduces to religious harmony.

${ }^{20}$ C. Taylor, "Why We Need A Radical Redefinition of Secularism," in The Power of Religion in the Public Sphere, ed. E. Mendieta and J. Vanantwerpen (New York: Columbia University Press, 2011), pp. 34-5. 
Taylor illustrates how these requirements evolved out of two divergent strands of Western secular democracy: French and American. More so than its Turkish counterpart, French secularism was born out of a reaction against religion; it sought to build a democratic ethos opposed to the authoritarian monarchism of the Catholic Church. Hence it sought to regulate all public religious expression that might be divisive in this regard. By contrast, American secularism was nurtured in a religiously diverse culture of Protestant and Deist worldviews that displayed far greater acceptance of democratic values. Because the Founders perceived religious intolerance, not religious hegemony, as the greater danger to democracy, their disestablishment of religion aimed mainly at ensuring its free exercise.

The history of American First Amendment jurisprudence illustrates the enduring tension between disestablishing religion and permitting its free exercise. On one hand, the on-going debate over obscenity laws - and the court's unwillingness to uphold anti-pornography ordinances that threaten political expression - shows that the court is conflicted about prohibiting forms of speech that may be offensive to religion-imbued community standards. On the other hand, by opposing state-imposed burdens on the exercise of religion (e.g., requiring parochial schools to meet certain academic standards) the courts have granted religious institutions free access to publicly funded services (e.g., special education for students with learning disabilities) and have permitted public funding for religion-based anti-drug counseling, parochial school vouchers, and modest official displays of religious observance. ${ }^{21}$

\footnotetext{
${ }^{21}$ As amended (2003), the Religious Freedom Restoration Act (RFRA) of 1993 prohibits the federal government (but not states) from excessively burdening the free exercise of religion.
} 
This history also illustrates how the inclusion of non-Protestant Christians, Jews, nonbelievers, and more recently, Native Americans, ${ }^{22}$ under First Amendment protection began only in response to challenges posed by Catholic and Jewish immigrants at the beginning of the twentieth century. The pluralization of religious factions propelled the drive toward inclusion, thereby confirming James Madison's view in Federalist Papers \#51 that fighting religious intolerance could be checked through securing a strategic balance of power between opposed factions. Madison's hope was that such a shifting modus vivendi would evolve into a principled compromise in which the desire among factions to impose their religion would be eclipsed by a universal recognition that no confession has an exclusive monopoly on the truth. Civic virtue and civility should disarm antagonism and engender true religious harmony based on shared devotion to justice and the common good.

Were he alive today, Madison might have faulted American courts for invoking technical legal theory to resolve America's on-going debate over whether secular humanism or theism should be privileged in interpreting freedom of religion and freedom of expression instead of allowing the people's representatives to decide this matter on their own. But as the French example shows, letting the people's representatives decide these matters need not guarantee a just and reasonable resolution; indeed, judging from the lively debate over prohibiting Muslim women from wearing the burqa in public spaces and Muslim girls from wearing the hijab in public schools, it is far from evident that the French people have properly balancing Taylor's requirements of religious freedom, equality, and non-hegemony against the competing

\footnotetext{
${ }^{22}$ In the wake of several Supreme Court decisions that denied Native Americans the right to claim religious exemptions to use peyote, the RFRA was amended in 1994 to expressly allow this use.
} 
requirement of religious fraternity, as interpreted by the hegemonic discourse of France's aggressively humanistic (or nationalistic) civil religion. ${ }^{23}$

\section{Part Three: Civil Discourse and Public Reason in Secular Democracy}

One might question whether the United States as a moderately secular polity or France as a more strongly secular polity has properly balanced religious freedom and religious disestablishment, which returns us to the controversy over Indonesia's blasphemy law. While human rights activists have criticized the law, my brief reference to American Constitutional practice as reflecting, in Madisonian terms, an evolving political compromise suggests that no standard of public reasonableness is completely neutral vis-à-vis competing values (be they secular or religious). Recall that religious sentiment based on monogenic theology - not primitive science based on polygenetic anthropology (propagated by Agassez, Morton, and Nott) - upheld the equal humanity of African slaves during the American abolitionist debate. The fact that antiblasphemy statutes descend from religion makes them no less reasonable than anti-obscenity laws, which have a religious pedigree as well. Although the American law banning obscenity and the Indonesian law banning blasphemy have different references (targeting expression that appeals to "prurient interests" in a patently offensive way and expression that "taints religion," respectively), which renders blasphemy laws comparably less secular than obscenity laws, the aim of both laws is to impose a majority's religious mores on a typically less religiously inclined

\footnotetext{
${ }^{23}$ The Stasi Commission ruled that wearing a less ostentatious sign than the foulard, which it wrongly viewed as an act of hostility toward the republic, would have been acceptable.
} 
minority. Failure to demonstrate the harmfulness of blasphemy and obscenity will not compel those offended by these forms of expression to desist from suppressing those who engage in them unless it can be shown that suppression is more harmful than toleration. This burden of proof, however, is easily met in most cases involving the denial of religious freedom. Ironically, many critics of blasphemy laws insist that secular democracy requires a far more restrictive speech code when debating and deliberating on public policy. Although few would disparage the expression of religious convictions in bearing public witness to the rightness or wrongness of policies, there are some who feel differently when it comes to political expression aimed at argumentative persuasion and reasoned deliberation. Doubtless many would agree with Taylor that including religious language in the public promulgation of laws, judgments, and executive decrees compromises the secular neutrality of the state (although the examples of Iraq and Pakistan noted above suggest that such language need not vitiate the secular legitimacy of the state tout court). But is it then inappropriate for elected representatives to appeal to religion in parliamentary debate? And, is it inappropriate for ordinary citizens to do the same when they debate public policy with persons who do not share their religious beliefs?

These questions arise whenever we ask why minorities who dissent from majoritarian policies have at least a prima facie duty to abide by them. The usual "you play by the rules, you accept the outcome" response to this query presumes that everyone recognizes the fairness of the rules. In order for the rules governing democratic politics to be fair, it is not enough that they allow everyone an equal vote and an equal right to speak out and associate freely. These safeguards against the worst kind of majoritarian tyranny - the violation of the minority's basic rights - do not address a less violent form of majoritarian "winner-take-all" tyranny. A fair democracy must also allow the minority an equal chance to be heard and responded to in a way 
that respects its ethical standpoint (assuming that that standpoint is tolerant of other standpoints). Losers as well as winners in democratic contests have a legitimate expectation that their concerns have been met with arguments whose premises they find to be reasonable - arguments whose reasons respect their own ethical standpoint even if they do not compel their assent. To rephrase this point in the language of deliberative democracy, some effort at rationally achieving a generally acceptable consensus on common interests, free from the constraints of hegemonic ideology and socio-economic power, must guide the process of public will formation and legislation in order for legal outcomes to merit the presumption of normative legitimacy (worthiness of recognition as prima facie morally binding); and this deliberative effort, whether successful or not in its consensual aim, cannot move forward unless citizens speak to one another in a mutually comprehensible and respectful language.

This is what John Rawls and other defenders of political liberalism have in mind when speaking of a civil duty to hew one's political thinking to public reason. ${ }^{24}$ Three questions arise as to its exercise: Who falls under the duty? Which political issues activate the duty? What does the duty require? Extreme secularists insist that this duty extends to all citizens, ordinary and official; applies to all political issues regardless of content; and requires that all religious reasons be bracketed. For instance, Robert Audi counsels the complete privatization of religious faith as a necessary condition for exercising civic responsibility. He insists that citizens bracket their

\footnotetext{
${ }^{24}$ J. Rawls, Political Liberalism; J. Habermas, Between Naturalism and Religion: Philosophical Essays, trans. C. Cronin (Cambridge: Polity Press, 2008). For a more detailed discussion of Habermas and Rawls on religion in the public sphere, see my Habermas: Introduction and Analysis (Ithaca: Cornell University Press, 2010), ch. 8.
} 
religious motives as well as religious language in deliberating about legislation. ${ }^{25}$ These sentiments are echoed by the Muslim secularist Lahouri Addi: "It is necessary to show how political modernity is incompatible with the public character of religion and how modernity is built on the depoliticization of religion." 26

A more moderate secularist might question the extreme requirement that ordinary citizens as well as parliamentarians debate and deliberate in accordance with such a demanding notion of public reason. One might also question applying the requirement to all policy debates regardless of their relevance to basic rights. Finally, one might dismiss the need to bracket religious motivations along with religious arguments. Addressing the issue of application, Rawls accepts the civility of religious argumentation in justifying policies that do not touch on constitutional freedoms or that only expand rather than restrict such freedoms. But debates over obscenity and hate speech (not to mention Indonesia's blasphemy law) illustrate that the distinction between constitutional and non-constitutional, freedom-restricting and freedom-enhancing, policies is hard to draw in practice. Virtually every form of expressive behavior can be interpreted as politically meaningful or provocative and harmful. Robust free speech potentially undermines the equal protection of some group(s), but efforts to control for the harmful effects of expressive behavior directly or indirectly infringe on constitutional liberty.

${ }^{25}$ R. Audi, "The Separation of Church and State and the Obligations of Citizenship," Philosophy and Public Affairs 18 (1989), pp. 278-79.

${ }^{26} \mathrm{~L}$. Addi, "Islamist Utopia and Democracy," The Annals of the American Academy of Political and Social Science 524 (November 1992), p. 124. 
The difficulty in distinguishing kinds of speech and speech regulation is made even harder in the case before us. Habermas and Rawls acknowledge that religious speech and thought are particularly recalcitrant to bracketing when it comes to things that matter most to people. Along with other relatively unquestioned comprehensive belief commitments, religion provides an authoritative anchor for deep moral convictions that cannot be acquired through science or other forms of practical thinking. These thinkers note the capacity of utopian religious imagery to expand our secular thinking about social justice and the unique dignity of the human person, as exemplified, for instance, in the American movement to abolish slavery. This belief in the importance of utopian, faith-based values in anchoring civil society also informs Soroush's notion of "religious democracy," which he opposes to the corrosive libertarianism of neo-liberal capitalism. For Soroush, democracy implies "respect for the will of the majority and the rights of others, justice, sympathy, and mutual trust," not to mention "tolerance in the domain of beliefs" and "fallibility in the domain of cognition." ${ }^{27}$ Democratic societies, he explains, "do not need to wash their hands of religiosity nor turn their backs on revelation" so long as they "absorb an adjudicative understanding of religion" based on "collective reason" and public "common sense." ${ }^{28}$ He therefore concludes that, "if the pluralism of secularism makes it suitable for democracy, the faithful community is a thousand times more suitable for it." 29

${ }^{27}$ Soroush, idem, pp. $125,152-53$

${ }^{28}$ Ibid., pp. 127-28, 140.

${ }^{29}$ Ibid., pp. 143-45. 
Like Soroush, Habermas and Rawls recognize that citizens in pluralist democracies should acknowledge the "burdens of judgment," which Rawls defines as an acknowledgement of the reasonableness of pluralism, or the impossibility of converting others' moral consciences to one's own way of thinking by means of rational suasion alone. We must acknowledge that from others' standpoints our most certain faith commitments are but subjective opinions, and that consensus on opinions remains at best a desideratum whose fulfillment leads beyond the realm of public reason.

Reconciling the civic duties of public reason with the legitimacy of religiously motivated political expression properly qualified by a reasonable acknowledgment of the burdens of judgment, Rawls and Habermas recommend MES. They allow the civility of robust religious rhetoric in debating and deliberating within the public sphere while insisting on its eventual translation into secular argumentation at the level of government. In order to ease the asymmetrical burden that falls on believers in meeting the requirements of public reason, Habermas suggests that even non-believers share in the duty to translate religious appeals into secular arguments.

A number of questions are raised by this proposal. To begin with, reconciling religious appeal to the demands of pubic reason might not require much, if any translation. For instance, Martin Luther King's quotation of the Bible in his "I Have a Dream Speech" - "There is neither Jew nor Gentile, neither slave nor free, nor is there female and male, for you are all one in Jesus Christ" (Galatians 3:28) - is readily comprehended by believers and non-believers alike as referencing the inherent dignity of the individual and the universal equality of all. Furthermore, as I noted earlier, secularization brings in its wake the rationalization of religious language. In Christian-majority and Muslim-majority countries, the ethical contents of the Abrahamic 
religious tradition (recall the Biblical passage quoted above) have already been translated into secular ideas, such as the idea of universal human rights. Finally, as the debates surrounding abortion, gay marriage, euthanasia, cloning, and stem cell research amply attest, advocates of religiously motivated policies have had little difficulty in finding secular arguments supporting their positions. These arguments, to be sure, might not express the main reasons why they advocate a policy. Arguing by conjecture - showing that a position can be justified by appeal to reasons that are convincing to one's opponent but not to oneself - need not be as duplicitous and insincere as it first appears, especially if the arguer announces his or her real (religious) motives for supporting her position. Perhaps this is all that Rawls and Habermas have in mind when they talk about translating religious appeals into the secular language of public reason. If that is so, then not just appeals to religion but appeals to any comprehensive worldview, however secular, will require translation into a more broadly shared idiom in order to convince others. ${ }^{30}$

Contrary to Rawls and Habermas, Taylor simply denies that religion poses a special challenge to secular democracy requiring special vigilance and separation. This challenge would not be so pressing if one could easily separate faith from reason, as Habermas and Rawls admonish us to do. But as the preceding discussion has shown, this cannot be done. What appears reasonable from the standpoint of public reason is invariably shaped by faith-anchored judgments.

Does that mean that there is little distinction to be drawn between religious and nonreligious faith commitments, as Taylor insists? Habermas mentions that purely religious faith commitments differ from non-religious faith commitments in several important respects. First,

\footnotetext{
${ }^{30}$ Taylor, "Why We Need a Radical Redefinition," pp.50-56.
} 
they impose themselves on the faithful only through personal revelation and conversion. Second, they command their fulfillment as a necessary condition for eternal salvation. Third, they command their fulfillment as the highest and most unconditional commands. ${ }^{31}$

The first and third traits mentioned above might not define religious commitments exclusively. Secular humanists also speak of epiphanies, revelations, and conversion experiences that explain their complex journey from believer to non-believer. People in general are reluctant to abandon core beliefs that are acquired more or less unconsciously over time and that have become deeply ingrained in their personal identities. Having emerged in ineffable experience, they ineffably color future experience, thereby creating a self-confirming circle of faith informing reason and vice versa. As for the third defining characteristic, secular faith commitments, such as the moral duty to protect even strangers from life-threatening mob persecution, can also command unconditionally, sometimes at great personal sacrifice.

The second trait, however, may seem to be peculiar to religion. The motivations for hewing to secular commitments appear less powerful than the promise of eternal salvation or the threat of eternal damnation vouchsafed by religion. It may therefore seem that religiously convicted people have less incentive to compromise and be persuaded by others for mundane reasons. Taken to the extreme of fanaticism, they demonize those who oppose them as emissaries of evil whose arguments must be resisted if not suppressed.

But religion does not have a monopoly on ideological extremism. Fanatics of all stripes have been willing to sacrifice mundane freedom, happiness, and commonsense for the sake of intangible rewards. Such fanatics can still speak the language of public reason; at the very least,

\footnotetext{
${ }^{31}$ J. Habermas, "Dialogue Between Habermas and Taylor," in The Power of Religion, pp. 61-62.
} 
they can conjecture how non-believers might be persuaded to agree with them. What they cannot do is conform themselves to the spirit of public reason.

So both Taylor and Habermas are mistaken; pace Habermas, the challenge to secular democracy is not that religious appeals resist translation into a secular idiom; pace Taylor, the challenge to secular democracy is not that particular creeds will contaminate the ideological neutrality of the state. Rather, the challenge to secular democracy is an unwillingness to be persuaded by others who might tempt us to compromise our deepest faith commitments. This undemocratic disposition is not unique to religion; nor is the disposition to demonize others who disagree with us. Rather, all organized ideological movements whose members display this disposition pose unique challenges to secular democracy.

\section{Part Four: Islam and Catholicism as Proponents of Secular Democracy}

Uncompromising faith commitments, of course, can also be enlisted in the service of promoting secular democracy. The historical confrontation between the Catholic Church and Western democracy, however, shows how exposure to religious pluralism and the subsequent need to compete for acceptance and influence can motivate fundamentalist movements to moderate and broaden their appeal in a secular direction. Strategic accommodation to secular democracy can evolve into principled acceptance; the same principles that once seemed so hostile to democracy can be drawn upon to promote it. This point is supported by the overwhelming number of predominantly Catholic countries that adopted secular democratic institutions in the last three decades of the twentieth century. I submit that it is also confirmed by Indonesia's more recent turn to secular democracy, in which Islamist parties played a decisive role. I conclude that the 
failure of these parties to temper their Islamic agenda, as evidenced by their unwillingness to change the blasphemy law, and the failure of the Constitutional Court to apply the law in a way that does justice to the Ahmadiya, belies principles of democratic pluralism and public reason that underlie Indonesia's uniquely religious-secular ethic of pancasila.

As I have mentioned, fear of Catholic fundamentalism provoked an extreme secular backlash in France and parts of Latin America that had the effect of confirming a self-fulfilling prophesy. Well into the twentieth century the Church defended positions that were hostile to liberalism and democracy. ${ }^{32}$ Critics blamed this illiberalism on the Church's highly centralized authoritarian structure and on its intolerance of other faiths, which followed from its stateassured monopoly on moral and religious instruction in many Catholic nations. But this tells only one side of the story. The Church's relationship to liberalism and democracy has always been shaped by its understanding of the threats arrayed against it. Anti-clerical legislation spurred on by nationalist republican sentiment in Europe and Mexico during the late nineteenth and early twentieth centuries may have succeeded in forcing the Church to accommodate liberal democracy up to a point, albeit mainly as an expedient in non-Catholic countries in which it did not enjoy a monopoly of influence - a fact which explains its reverse accommodation to antiCommunist governments of a virulent Fascist stripe. Only after the Second World War did the Church desist from seeking hegemony while embracing freedom of religion as an intrinsic

\footnotetext{
${ }^{32}$ I discuss these positions in "Civility and Legitimacy: The Ambivalent Role of Religion in Transitional Democracy," in Democracy, Culture, and Catholicism, ed. M. Schuck (New York: Fordham University Press, 2014).
} 
value. ${ }^{33}$ By the time the Vatican II reform culminated in declaring religious liberty with Pope Paul VI's Dignitatis Humanae (1965) - partly under pressure from American Catholics led by John Courtney Murray and partly out of an evolving understanding of its own natural law tradition dating back centuries ${ }^{34}$ - the Church was well positioned to become the chief champion of human rights and democracy throughout Latin America and Eastern Europe. ${ }^{35}$

The Church's entry into politics was partly motivated by strategic considerations that fell far short of the principled endorsement of secular democratic ideals that had been emerging with its continuous re-examination of its own natural law teaching. Nevertheless, these strategic considerations themselves might have helped motivate the Church to move beyond a modus vivendi acceptance of democracy to a more principled embrace of it. From a strategic point of view, ${ }^{36}$ movements with strong ideological commitments are propelled to moderate their

\footnotetext{
${ }^{33}$ John XXIV's encyclical Pacem in Terris affirmed human rights and citizenship participation in government. A stronger commitment to liberal democracy appeared two years later in the Second Vatican Council's Gaudium et Spes.
}

${ }^{34}$ Anthony Mansueto, "Religion, Pluralism, and Democracy: A Natural Law Approach"; Edward Bell, "Catholicism and Democracy: A Reconsideration"; Paul Sigmund, "The Catholic Tradition and Modern Democracy, “ The Review of Politics, 49/4 (Autumn, 1987), pp. 530-548.

${ }^{35}$ Besides Murray's writings, Jacques Maritain's The Rights of Man and the Natural Law (1943), Yves Simon's Philosophy of Democratic Government (1951), and Heinrich Rommen's The State in Catholic Thought (1945) defended liberal democracy on Catholic grounds.

${ }^{36}$ See Carrie Wickham, "The Path to Moderation: Strategy and Learning in the Formation of Egypt's Wasat Party," Comparative Politics 36(2) (January 2004), pp. 205-228, and Jillian Schwedler, Faith in Moderation: Islamist Parties in Jordan and Yemen (Cambridge: Cambridge University Press, 2008). For an insightful application of this theory to Muslim reform politics in Iran and Turkey, see Tezcür, Paradox of Moderation. 
agendas in order to avoid government suppression, win elections, and develop an organizational leadership consisting of professionally trained lawyers, economists, and other professionals capable of proposing and implementing realistic solutions to a wide range of social problems. Once these movements come to appreciate the reciprocal benefits to themselves and other likeminded movements of political liberalism, they come to endorse secular democracy and political liberalism for its intrinsic justice, and converge toward an overlapping consensus in grounding these ideals in the "truth" conveyed by their own incommensurable doctrines.

These factors were evident in the transformation of revolutionary socialist movements in Europe into moderate social democratic parties in the twentieth century, and they doubtless influenced the moderation of emergent Christian democratic parties around the same time. Once again, while it might be tempting to explain this trajectory of ideological moderation as simply strategic, the Church's decision to enter democratic political life was also motivated by reflection on natural law teaching regarding human dignity, social justice, and limited power sharing. ${ }^{37}$

Samuel Huntington observes that the "third wave" of democratization from 1974 to 1990 was "overwhelmingly a Catholic wave," with roughly three-quarters of the thirty countries transitioning to democracy being predominantly Catholic. ${ }^{38}$ Among the beneficiaries of this wave were Peru, where the Church took an active role in organizing the urban and rural poor in accordance with liberation theological precepts while condemning the anti-democratic and antiliberal revolutionary violence of the Shining Path (from the late 80s through the 90s the Church

37

Günes Tezcür, Paradox of Moderation, pp. 64-76.

38

Samuel P. Huntington, The Third Wave: Democratization in the Late Twentieth Century (Norman: University of Oklahoma Press, 1991), p. 91. Also see Daniel Philpott, “The Catholic Wave," Journal of Democracy 15/2 (2004), pp. 32-46. 
also condemned the counter-revolutionary violence, authoritarianism, and corruption of the Garcia and Fujimori governments). Meanwhile, in Lithuania, with a Catholic majority of 81 per cent, the Church opposed the communist regime by strongly advocating on behalf of liberal constitutional principles and human rights.

What made the Church's role as a promoter of liberal democratic reform possible in these countries? In both Peru and Lithuania the Church was a part of a national identity that had traditionally stood apart from the state. The willingness of the Church to separate itself from the state in these countries enabled it to become more accepting of liberal democracy and vice versa - "twin tolerations" (as Alfred Stepan puts it) ${ }^{39}$ that vindicate Tocqueville's insights, made in reference to American democratic secularism, that church-state separation increases the political power and prestige of religious associations. Hence, it is not surprising that the Church's clout in moving authoritarian regimes toward liberal democracy was strongest where it refused to accommodate the state (its clout was weakest in countries like Portugal and Spain, where the Church received privileges in exchange for supporting dictatorship). Thus, given its support for the former Franco dictatorship, the Spanish Church was in no position to aggressively press its own religious agenda on divorce and abortion in the public sphere, and instead chose to play a subdued role in the new democracy. By contrast, in Poland, the Church parlayed its longstanding prestige as chief antagonist to the Communist regime by pushing for privileged legal recognition within the new constitutional order.

Alfred Stepan, "Religion, Democracy, and the 'Twin Tolerations,"” Journal of Democracy 11 (October 2000), pp. 37-57. 
As my own research on the Peruvian and Lithuanian Churches has shown, ${ }^{40}$ Catholicism has become a potent catalyst for democratic secularization when it has asserted its independence from government while at the same time using its governmental influence cautiously to promote broadly secular social justice agendas in civil society. The privileged place enjoyed by the Peruvian Church is partly a function of its independence from the state and partly a function of its role as chief dispenser of health, welfare, and education. In playing a predominant role in Peru's democratic civil society it has had to present both a "public" face, as defender of human rights, fraternity, national reconciliation, and the common good, as well as a "private" face as promoter of an orthodox creed that increasingly finds less support among Peruvians, who are more open to alternative lifestyles. The less favored position enjoyed by the Lithuanian Church, by contrast, might reflect its relative inability to break out of a narrow sectarian standpoint and diversify its message so as to embrace broader struggles for social justice in the face of growing inequalities caused by capitalism.

The case of Indonesia's democratic revolution presents a contrast to the Lithuanian case, more strongly resembling the Church's role in Peru, with its uniquely religious promotion of secular democracy. In fact Islamic organizations were at the forefront of Indonesia's revolution. Abdurrahman Wahid, senior Islamic cleric, headed Indonesia’s largest Muslim organization, The Awakening of Religious Scholars (Nahdlatul Ulama [NU]). Amien Rais, who joined Wahid in the struggle against Suharto, led the second largest Muslim organization, Muhammadiyah, and helped focus student demands on democracy. While Rais went on to create a new political party, the National Mandate Party (PAN) that was not Islamist and whose leadership contained non-

40

See "Civility and Legitimacy" (supra). 
Muslims, Wahid formed his own Islamic political party, the National Awakening Party (PKB), that expressly rejected the idea of an Islamic state in favor of a religiously pluralistic one. In keeping with the pluralistic tenor of his party, he joined in an alliance with the secular nationalist party of Megawati Sukarnoputri, the Indonesian Democratic Party-Struggle (PDI), which included secular Muslims, Christians, and non-Muslim minorities. Wahid was subsequently elected Indonesia's first president.

Secular public reason was on full display during the transition to the new regime. Following Suharto's resignation, groups representing almost all sectors of society endorsed the establishment of a democratic government. In the 1999 elections it became apparent that Islamic parties (such as the PKB and PAN) that did not focus on single-issue messages based on political Islam fared better than those (such as the Crescent Star Party [PBB]) that did (PKB won $12 \%$ and PAN $7 \%$, while PBB won only 2\%). The message was clear: pious Muslims who constituted an overwhelming majority of the population were also interested in issues revolving around any emergent market economy: health, welfare, security, jobs, and basic subsistence. Those political Islamist parties (such as the Prosperous Justice Party [PKS]) that abandoned single-issue politics in order to broaden their appeal to moderate and liberal Muslims saw dramatic improvements in their popularity in the elections of 2004 (from 1.7 to $7.4 \%$ ) and 2009. Another step forward occurred in 2009, when PKS and the United Development Party (PPP) joined with PAN and PKB to re-elect the government of Yudhoyono, a former army general and corruption fighter, who is a member of the secular Democratic Party (PD).

The mainstreaming of Islamist parties has had a reciprocal impact on substantive legislative outcomes. Policies that permit local shari'a ordinances and ban blasphemy are moderated by the fact that they are often enacted with the support of many secularists. For 
instance, in 2009 Aceh's legislature passed a "stoning law" based on shari'a that expressly punished adulterers and other religious offenders. Less publicized was the fact that that this act was intended as a parting shot by a legislative majority that had just been voted out of office. The law was vetoed by Aceh's democratically elected governor, Irwandi Yusuf, himself a pious Muslim who recently visited Mecca, and has not been taken up by the new legislature. In the meantime Yusuf has reined in Aceh's Islamic "police" in his pursuit of social policies revolving around increased spending on education and welfare and restrictions on logging. Although Yusuf was voted out of office in 2012 for allowing a palm oil concession in a protected habitat, Aceh's legislature continues to demonstrate a commitment to democratic accountability that exhibits a considerable degree of republican civility on the part of moderate Muslims and all who are principally concerned about environmental protection and other "universal" issues that transcend religion.

Apparently, toleration of Islamist organizations within civil society has in large part induced a corresponding moderation and broadening of Islamist platforms and arguments. Importantly, even when not prevailing in competitive elections these organizations have managed to combine strategies for partially fulfilling strictly religious aims, such as the passage of blasphemy laws, with commitment to republican ideals of civil discourse. ${ }^{41}$

While human rights advocates have criticized Indonesia's acceptance of "stealth Islamization" as an affront to religious freedom and disestablishment, Indonesia's predominantly Muslim legislature may eventually moderate its most controversial provision, the blasphemy law, in accordance with the country's republican doctrine of pancasila. Combining two Sanskrit

41

T. Pepinsky, et. al. , "Indonesian Democracy and the Transformation of Political Islam," Lembaga Survei Indonesia, 6-7 (http://www.lsi.or.id/riset/385/Indonesian\%20Democracy).Posted March 22, 2010. 
words: panca (five) and sila (principle), the doctrine affirms: (1) the existence of one universal God; (2) a just and civilized humanity; (3) the unity of Indonesia; (4) democracy guided by the inner wisdom in the unanimity arising out deliberations among representatives; and (5) social justice for the whole of the people of Indonesia. These principles were fashioned by President Sukarno in 1945 as a synthesis of monotheism, socialism, and nationalism and incorporated into the constitution. Although the first principle has been criticized for excluding polytheism, atheism, and agnosticism, its scope is secular and universal, providing an ontological foundation for human rights and social justice oriented toward a common good.

We now see why Indonesia's highest court stands in violation of the constitution it is supposed to defend when it fails to protect the religious freedom of minorities, such as the Ahmadiya ${ }^{42}$ Simply put, the constitution's pancasilan ethos mandates that its provisions be interpreted in conformity with principles of liberal toleration and republican civility. The broader lesson to be drawn from this, however, is that Islamist political movements must relinquish some of their religious platform for the sake of furthering the liberal and republican ideals inherent in secular democracy. As in the case of Catholicism, this outcome is more likely to occur within polities wherein multiple religions compete for political influence through embracing social justice concerns, political culture encourages deliberative compromise and constitutional power-sharing, and the judiciary aggressively defends freedom of speech and minority rights.

\section{Concluding Remarks: The Ambivalent Role of Religion in Public Life}

42

See Tezcür, Paradox of Moderation and "Constitutionalism." 
Political Catholicism and political Islam have been demonized as impediments to democracy. I submit that the real threats to democracy have been authoritarian governments and a rapacious form of global capitalism that has exacerbated social divisions, threatened stable communities, and weakened the power of popularly elected regimes to care for their neediest citizens. Indeed, the record shows that moderate religious political movements are especially adept at promoting democratization and liberalization because of their uncompromising commitment to social justice. The record does not show, however, that moderate religious reform movements are more successful at promoting democratization than more militant and perhaps less secular political movements; for it may be the case that radical movements are less willing than moderate movements to compromise with corrupt authoritarian regimes that masquerade as formal democracies. ${ }^{43}$

Left unmentioned in my account is the enormous literature on the democratic moderation of Islamist reform movements. In summarizing some of this recent literature, Jillian Schwedler notes that standard "inclusion-moderation" theories that emphasize the causal priority of group behavior (strategically motivated political participation) in moderating group ideology overlook the fact that moderate behavior does not necessarily imply moderate ideology; that group ideology is as likely to explain group behavior; and that internal group debate on the compatibility of pluralistic democracy with a group's Islamic commitments is often decisive in determining whether a group moderates its religious platform. ${ }^{44}$ But more important, for that debate to happen and be resolved to the satisfaction of rank and file membership, charismatic

${ }^{43}$ See G. Tezcür, Paradox of Moderation.

${ }^{44} \mathrm{~J}$. Schwedler, "Can Islamists Become Moderates? Rethinking the Inclusion-Moderation Hypothesis, World Politics, 63/2 (April, 2011), pp. 347-76, esp. p. 360. 
leaders who have engaged in public reasoning with representatives of opposing viewpoints must have already re-imagined the group's Islamic commitments in a way that moves a majority of the group's members from a strategic accommodation to pluralist democracy toward a more principled embrace of it - a conjectural reasoning from Islamic premises that has the potential to encourage moderate epistemic secularism.

As Andrew Marsh observes in discussing the capacity of moderate Islamic leaders within Western democracies (such as Tariq Ramadan $)^{45}$ to conjecture about how Islamic values might support political liberalism, the absence of any concrete statement of underlying values and principles in Islamic law opens up a space for Muslims residing in these democracies to reinterpret Islam's traditional rule-commanding observance of contracts in accordance with a social contractarian consent to abide by liberal democratic institutions. ${ }^{46}$ Accompanying this commitment is a commitment to social justice for Muslims and non-Muslims alike, expanding the community of civil solidarity beyond fellow Muslims to include all those with whom Muslims are "contractually bound" by ties political, social, and economic. In this way Muslims learn to view the core social justice values of their own faith as free-standing and faithtranscending- universal, multicultural, and secular. Epistemic secularism in this moderate form can reconcile a strongly religious background culture to secular institutions and secular politics in the manner prescribed by political liberalism. It can also foster critical dialog among Muslims about the meaning of Islamic social values, leading, in turn, to greater civil participation in democracy (and, conversely, greater democratic moderation of Islamic demands).

\footnotetext{
${ }^{45}$ T. Ramadan, To Be a European Muslim (Leicester: Islamic Foundation, 1999).

${ }^{46}$ A. F. Marsh, "Reading Tariq Ramadan: Political Liberalism, Islam, and "Overlapping Consensus," Ethics \& International Affairs, 21/4 (Winter 2007).
} 
It would be premature to conclude from what I have said above that political Islam can embrace secular democracy without relinquishing at least some of its power and identity. As our discussion of the most recent waves of democratization clearly attests, a paradox exists in enlisting this power and identity in service to a mundane end whose realization would entail its diminution (or dilution). Unlike purely secular movements that risk life and limb in pursuit of ending oppression, religious movements that seek justice by realizing God's Kingdom on earth may seem to have more powerful incentives for doing so, but they may also face greater challenges in accommodating justice for all.

A secular democracy which incorporates both liberal and civic republican values may be the best worldly approximation of that Kingdom. That the dignity of the individual instantiated in the liberal defense of human rights can degenerate into a nihilistic worship of unrestrained individual self-assertion unless coupled with a civic republican devotion to justice and a common good conception of the rule of law has been a mainstay of democratic theory for over three hundred years. Both Weber and Durkheim warned us of this secular danger, as do moderate Muslim secularists like Soroush, who counsel against equating democracy with a strongly secular, morally eviscerated liberalism. ${ }^{47}$ We know from our experience with the secular "political theologies" of the twentieth century - nationalism, fascism, and communism - that this danger can provoke a fundamentalist backlash. A "formal democracy" that does nothing more than protect against government tyranny by delivering political life over to powerful interests and economic aggregation of selfish preferences is fertile soil for its cultivation.

${ }^{47}$ Idem, p. 125. 
Democracy premised on the dignity of the individual and the common good must encompass respect for public reason and the rule of law. The Indonesian ideal of civic deliberation ensconced in pancasila encompasses both aims. In upholding the possibility of achieving consensus on a common good, this ideal expresses a religious belief in the unconditional dignity of the individual and of a higher justice, which it opposes to the divisiveness and inequality of a market-based democracy ruled by selfish preferences. In supplementing personal revelation with rational dialogue as a method for discovering this good, the ideal leaves open the possibility that consensus may not be reached, that something like an agreement to disagree, coupled with an agreement to compromise on some issues and tolerate individual differences of opinion, may be inevitable. The historical confrontation of Catholicism and democracy in the last century, no less than the parallel confrontation of Islam and democracy in the present one, might seem to suggest that compromise invariably resolves itself in the form of a strategic modus vivendi, in which toleration of the other is suffered out of necessity rather than embraced for its own sake. Such may be the case initially, but the stories told here offer hope for a more civil resolution. 
